\title{
PENGARUH JUMLAH RAGI DAN WAKTU FERMENTASI PADA PEMBUATAN BIOETANOL DENGAN BAHAN BAKU AMPAS TEBU
}

\author{
Dewi Putri Yuniarti ${ }^{1}$,Surya Hatina ${ }^{2}$, Winta Efrinalia ${ }^{3}$ \\ ${ }^{1,2)}$ Dosen PNSD dpk Program Studi Teknik Kimia Universitas Tamansiswa Palembang \\ email : dewiputriyuniarti@yahoo.com \\ email : surya@unitaspalembang.ac.id \\ ${ }^{3)}$ Mahasiswa Teknik Kimia Universitas Tamansiswa Palembang \\ email : efrinaliawinta@gmail.com
}

\begin{abstract}
ABSTRAK
Kebutuhan energi yang mengalami peningkatan,sedangkan cadangan fosilterus mengalami penurunan seiring dengan penggunaannya. Tingginya penggunaan energi ini mendorong untuk dikembangkannya energi alternatif seperti pemanfaatan biomassa salah satunya yaitu bioetanol. Bahan baku dalam pembuatan bioetanol yaitu biomassa yang mengandung selulosa, hemiselulosa dan lignin salah satunya adalah ampas tebu. Ampas tebu merupakan limbah padatan dari pengolahan industri gula yang volumenya bisa mencapai 30-40\% dari tebu giling yang dapat menyebabkan pencemaran lingkungan dan aroma tidak sedap pada lingkungan jika tidak dimanfaatkan. Ampas tebu memiliki kandungan selulosa yang cukup tinggi untuk diolah menjadi energy alternative bioetanol. Penelitian ini bertujuan untuk memanfaatkan limbah ampas tebu menjadi bioetanol melalui proses fermentasi menggunakan ragi Saccharomyces cerevisiae dengan variasi penambahan ragi sebanyak 1 gram \% b/v, 3 gram \% $\mathrm{b} / \mathrm{v}$, dan 5 gram $\%$ b/v dari masa awal ampas tebu dengan lama waktu fermentasi 5 hari, 6 hari, 7 hari, 8 hari, dan 9 hari. Hasil penelitian menunjukkan kadar bioetanol tertinggi sebesar 4,9100\% dihasilkan dari penambahan ragi 5 gram \% b/v dengan lama waktu fermentasi 7 hari.
\end{abstract}

Kata kunci : Bioetanol, Fermentasi ,Ragi

\section{PENDAHULUAN}

Pertumbuhan indsutri dan pertumbuhan populasi di Indonesia yang semakin meningkat menyebabkan tingginya tingkat kebutuhan energi, termasuk konsumsi bahan bakar fosil. Pada kenyataannya ketersediaan bahan bakar fosil yang dikonsumsi saat ini semakin kecil dan tidak dapat diperbaharui. Sehingga bahan bakar alternatif diharapkan bisa menyelesaikan masalah kurangnya sumber energi saat ini. Salah satu bentuk dari energi terbaru yaitu pemanfaatan sumber biologi baik dari hewan maupun tumbuhan yang disebut biomassa. Salah satu contoh biomassa adalah bioetanol.

Bioetanol terbentuk melalui fermentasi glukosa yang dihasilkan melalui proses hidrolisa selulosa. Dalam pembentukan bioetanol, selulosa adalah bahan baku yang paling banyak diolah dan diperoleh dari tumbuhan. Ampas tebu salah satu contoh dari bahan tumbuhan yang mengandung selulosa dan dapat dijadikan sumber alternatif, hal ini dikarenakan pemanfaatan tebu hanya terbatas pada pengolahan airnya saja, sementara ampas tebu biasanya tidak terpakai atau menjadi limbah. Hal ini menyebabkan ketersediaan ampas tebu yang sangat melimpah dan dapat berpotensi untuk dijadikan bahan baku bioetanol. 
Ampas tebu adalah bahan yang mengandung serat kasar berupa senyawa lignoselulosa (senyawa kompleks hemiselulosa, selulosa, dan lignin) yang potensial untuk dikembangkan menjadi sumber energi seperti bioetanol. Untuk memperoleh bioetanol yang terdapat pada ampas tebu dilakukan melalui proses fermentasi.

Ampas tebu belum dimanfaatkan secara baik sehingga hanya menjadi limbah. Hal ini patut menjadi penelitian untuk mengetahui besar kadar alkohol yang dapat dihasilkan dari ampas tebu. Pada penelitian ini dilakukan proses fermentasi menggunakan penambahan ragi dengan kosentrasi dan lama waktu yang bervariasi. Dengan ini diharapkan limbah ampas tebu dapat diolah secara optimal untuk menghasilkan energi alternatif yang dapat menggantikan bahan bakar minyak.

Penelitian mengenai proses pembuatan bioetanol atau tahap-tahapan pada lignoselulosik etanol dengan bahan baku dan proses yang beragam telah banyak dilakukan serta dipublikasikan dalam bentuk jurnal maupun artikel ilmiah yang tentunya menambah informasi mengenai proses pembuatan bioetanol. Adapun beberapa penelitian yang menjadi rujukan dan referensi pendukung dalam proses penelitian ini adalah pada proses pretreatment atau proses delignifikasi yang merujuk pada hasil penelitian (Ida, 2011) dan (Harry, 2014). Kemudian, proses hidrolisis yang merujuk pada hasil penelitian (daniel, 2012).

Rumusan masalah pada penelitian ini adalah bagaimana pengaruh jumlah ragi terhadap ampas tebu pada proses fermentasi untuk menghasilkan bioetanol dan bagaimana pengaruh lama waktu fermentasi ampas tebu terhadap kadar bioetanol yang dihasilkan.

Tujuan dari penelitian ini adalah mengetahui pengaruh jumlah ragi terhadap ampas tebu pada proses fermentasi untuk menghasilkan bioetanol dan mengetahui pengaruh lama waktu fermentasi ampas tebu terhadap kadar bioetanol yang dihasilkan.

Hipotesa dari penelitian ini adalah semakin besar jumlah ragi yang digunakan pada proses fermentasi maka semakin tinggi kadar bioetanol yang dihasilkan dan semakin lama waktu fermentasi yang digunakan maka akan semakin tinggi kadar bioetanol yang dihasilkan.

Ruang lingkup penelitian ini adalah perbandingan masa ampas tebu dan pelarut adalah 1 gram : $20 \mathrm{ml}$, Proses delignifikasi menggunakan larutan $\mathrm{NaOH} 6 \%$, temperatur dan waktu delignifikasi adalah $121^{\circ} \mathrm{C}$ dan 30 menit, konsentrasi $\mathrm{HCl}$ yang digunakan adalah $0,3 \mathrm{~N}$ selama 120 menit, kosentrasi ragi yang digunakan adalah 1 gram $\% \mathrm{~b} / \mathrm{v}, 3$ gram $\% \mathrm{~b} / \mathrm{v}$, dan 5 gram $\% \mathrm{~b} / \mathrm{v}$, jenis ragi adalah ragi roti (Saccharomyces Cerevisiae), waktu fermentasi yang digunakan dalah $(5,6,7,8,9)$ hari.

Manfaat dari penelitian ini adalah mengetahui pengaruh jumlah ragi terhadap ampas tebu pada proses fermentasi untuk menghasilkan bioetanol, mengetahui pengaruh lama waktu fermentasi ampas tebu terhadap kadar bioetanol yang dihasilkan limbah ampas tebu dapat dimanfaatkan secara optimal untuk sumber bahan bakar altenatif, memberikan nilai jual pada limbah ampas tebu

\section{TINJAUAN PUSTAKA}

Ampas tebumerupakan limbah padat dari pengolahan industri gula tebu yang volumenya mencapai $30-40 \%$ dari tebu giling. Saat ini perkebunan tebu rakyat mendominasi luas areal perkebunan tebu di Indonesia. Ampas tebu termasuk biomassa yang mengandung lignoselulosa sangat dimungkinkan untuk dimanfaatkan menjadi sumber energi alternatif seperti bioetanol atau biogas.

Ampas tebu, atau disebut juga dengan bagas, adalah hasil samping dari proses ekstraksi cairan tebu. Ampas tebu sebagian besar mengandung ligno-cellulose. Panjang seratnya antara 1,7-2 mm dengan diameter sekitar $20 \mu \mathrm{m}$, sehingga ampas tebu ini dapat memenuhi persyaratan untuk diolah menjadi papan-papan buatan. Serat bagas tidak dapat larut dalam air dan sebagian besar terdiri dari 
selulosa, pentosan, dan lignin (Allita dkk, 2012). Hasil analisis serat bagas tercantum dalam Tabel 1 (sudaryanto dkk, 2002)

Tabel 1. Komposisi Kimia Ampas Tebu

\begin{tabular}{|c|c|}
\hline Kandungan & Kadar (\%) \\
\hline Abu & 3 \\
\hline Lignin & 22 \\
\hline Selulosa & 37 \\
\hline Sari & 1 \\
\hline Pentosa & 27 \\
\hline $\mathrm{SiO}_{2}$ & 3 \\
\hline
\end{tabular}

Ragi biasanya mengandung mikroorganisme yang melakukan fermentasi dan media biakan bagi mikroorganisme tersebut. Media biakan ini dapat berbentuk butiran-butiran kecil atau cairan nutrien. Ragi umumnya digunakan dalam industri makanan untuk membuat makanan dan minuman hasil fermentasi seperti acar, tempe, tape, roti, dan bir. Saccharomyces cerevisiae merupakan salah satu spesies ragi yang memiliki daya konversi gula menjadi bioetanol dengan baik.

Saccharomyces cerevisiae merupakan genus khamir/ragi/yeast yang memiliki kemampuan mengubah glukosa menjadi alkohol dan $\mathrm{CO} 2$. Saccharomyces cerevisiae merupakan mikroorganisme bersel satu tidak berklorofil, termasuk kelompok Eumycetes. Tumbuh baik pada suhu $30{ }^{\circ} \mathrm{C}$ dan $\mathrm{pH}$ 4,8. Beberapa kelebihan Saccharomyces cerevisiae dalam proses fermentasi yaitu mikroorganisme ini cepat berkembang biak, tahan terhadap kadar alkohol yang tinggi, tahan terhadap suhu yang tinggi, mempunyai sifat stabil dan cepat mengadakan adaptasi.

Lignoselulosa merupakan bahan penyusun tanaman yang mengandung tiga komponen utama yaitu selulosa (30-50\% berat), hemiselulosa (15-35\% berat), danlgnin (13-30\% berat) (Gunam, dkk, 2011).Gabungan dari tiga komponen tersebut menjadi penyusun kompleks pada dinding sel tumbuhan. Bagian terbesar yaitu sekitar 30-6-\% dari total massa kering lignoselulosa adalah selulosa (Axelsson, 2011). Selulosa dengan rumus molekul $\left(\mathrm{C}_{6} \mathrm{H}_{10} \mathrm{O}_{5}\right)$ n, merupakan penyusun utama dinding seltanaman yang berwarna putih dan berbentuk serat. Selulosa tidak larut dalam air dan tidak dapat dicerna oleh tubuh manusia. Hampir 50\% karbohidrat yang berasal darit umbuhan di dominasi oleh selulosa (Wiratamaja, dkk., 2011).

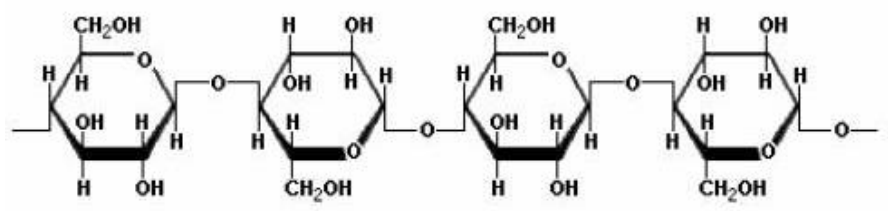

Gambar 1.Struktur Kimia Selulosa (Axelsson, 2011)

Selulosa adalah polisakarida generasi kedua dari glukosa sebagai struktur yang berserat dan mempunyai hydrogen bond atau jembatan hidrogen yang kuat.Selulosa memiliki ikatan yang kuatdan tidak larut dalam kebanyakan pelarut. Tetapi selulosa akan larut dalam larutan asam mineral dengan konsentrasi tinggi (akibat hidrolisis). Sifatfisik selulosa adalah tidak larut dalam eter dan alkohol, padat, berwarnaputih, dan kuat. Monomer selulosa atau yang disebut glukosa merupakan hasil hidrolisis sempurna dari selulosa, sedangkan selobiosa yang merupakan disakarida dari selulosa dihasilkan dari hidrolisis tidak sempurna (Ningrum, 2015).

Komponen kedua dari lingnoselulosa adalah hemiselulosa, sekitar $25-30 \%$ dari total massa kering. Hemiselulosa merupakan polimer bercabang yang tersusun atas heksosan dan pentosan. Molekul hemiselulosa bersifat plastis, lebih mudah menyerap air dan mempunyai permukaan kontak 
antarmolekul yang lebih luas dari selulosa (Wiratamaja, dkk., 2011). Hemiselulosa relatif mudah dihidrolisis oleh asam menjadi komponen monomernya. Hemiselulosa dapat diisolasi dengan cara ekstraksi menggunakan dimetilsulfoksida dan alkali $(\mathrm{KOH}$ dan $\mathrm{NaOH})$. Hemiselulosa berfungsi sebagai bahan pendukung dalam dinding sel dan berlaku sebagai perekat antara sel tunggal yang terdapat didalam batang tanaman. Perbedaan hemiselulosa dengan selulosa yaitu hemiselulosa mudah larut dalam alkali tapi sukar larut dalam asam, sedangkan selulosa adalah sebaliknya (Ningrum, 2015).

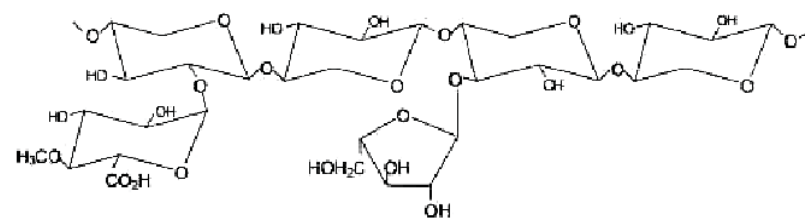

Gambar 2.Struktur Kimia Hemiselulosa (Walker, 2010)

Salah satu zat komponen penyusun tumbuhan dikenal dengan lignin. Komposisi pada lignin ini berbeda-beda tergantung jenisnya. Lignin tersusun atas jaringan yang menguatkan ikatan antara hemiselulosa dan seratselulosa sehingga sulit dipisahkan (Wiratamaja, dkk., 2011). Lignin menunjang struktur dinding sel tumbuhan, sekitar $15-30 \%$ total massakering. Lignin memiliki berat molekul yang bervariasi antara 1000-20.000, tergantung pada sumber biomassanya (Axelsson, 2011).Lignin relatif stabil terhadap aksi kebanyakan larutan asam mineral, tetapi larut dalam larutan basa panas dan larutan ion bisulfit $\left(\mathrm{HSO}_{3}\right)$ panas. Lignin menyebabkan terjadinya perekatan antarsel sehingga lignin tidak dikehendaki karena menghambat proses hidrolisaselulosa.

Bioetanol adalah etanol yang berasal dari makhluk hidup, dalam hal ini adalah bahan nabati. Bioetanol adalah bahan bakar alternatif yang diolahsumberbiologiyaitutumbuhan, dimana memiliki keunggulan mampu menurunkan emisi $\mathrm{CO}_{2}$ hingga 19-25\%.Penambahanbioetanolsebesar $3 \%$ pada bensin dapat menurunkan emisi $\mathrm{CO}_{2}$ sebesar $1,3 \%$ (Fatmawati dan Agustriyanto, 2015). Esensi peraturan Menteri ESDM adalah kewajiban bagi campuran bahan bakar nabati dengan persentase tertentu bagi sektor transportasi mulai 2009 (Beni dkk, 2013). Bioetanol ini dibuat melalui proses hidrolisis dan fermentasi. Bioetanoldapatdihasilkandarigulasederhana, pati, dan selulosa .Etanol merupakan zat cair, berbau khas, tidak berwarna, mudah menguap dan terbakar serta dapat bercampur dalam air.

Ketika bioetanol dihasilkan dari biomassa yang mengandung pati atau selulosa, maka bioetanol mampu menjadi bioenergi.Salah satu proses pembuatan bioetanol dalam industri dengan cara fermentasi. Proses fermentasi dilakukan dengan memakai berbagai macam bahan baku. Bahan baku yang umum digunakan antara lain :

\section{Sugar}

Bahan - bahan ini mengandung gula atau disebut substansi sakarin yang rasanya manis. Bahan ini berasal dari gula tebu, gula bit, molase (tetes) buah-buahan yang langsung dapat difermentasikan menjadi alkohol.

\section{Starches}

Starches adalah bahan yang mengandung pati, gandum, kentang, akar tumbuh-tumbuhan, jagung, ubi kayu, padi-padian dan lain-lain. Bahan jenis ini terlebih dahulu harus dihidrolisa dengan bantuan enzim atau katalis asam terlebih dahulu, agar dapat menjadi gula, lalu difermentasikan menjadi etanol.

\section{Cellulose Material}

Bahan-bahan ini mengandung sellulosa, misalnya ampas kelapa, kayu, ampas tebu, kulit kerang, waste sulft liquor yang merupakan residu dari pabrik pulp dan kertas. Untuk menghasilkan etanol sellulosa harus dihidrolisa dengan mineral atau larutan asam sebelum difermentasikan. 
Tabel 2. Sifat Fisika Etanol

\begin{tabular}{ll}
\hline \multicolumn{1}{c}{ Sifat-sifatfisiketanol } & \multicolumn{1}{c}{ Keterangan } \\
\hline Berat Molekul & $46,07 \mathrm{gr} / \mathrm{gmol}$ \\
Titik Lebur & $-112^{\circ} \mathrm{C}$ \\
Titik Didih & $78,4^{\circ} \mathrm{C}$ \\
Indeks Bias & $0,7893 \mathrm{gr} / \mathrm{ml}$ \\
Viskositas $20^{\circ} \mathrm{C}$ & $1,36143 \mathrm{cP}$ \\
Panas Penguapan & $1,17 \mathrm{cP}$ \\
Warna Cairan & Tidakberwarna \\
Kelarutan & Larutdalam air daneter \\
Aroma & Memiliki aroma yang khas \\
\hline
\end{tabular}

(Sumber : Perry's Chemical Engineers Handbook, McGraw Hill Book

Company7 the Edition, 1999)

Proses pengolahan lignoselulosa menjadi etanol terdiri dari empat tahap utama, yaitu pretreatment (perlakuan awal), hidrolisis, fementasi,dan pemisahan produk/purifikasi (Mosier, dkk. 2005).

Tujuan dari tahap pretreatment adalah untuk menghilangkan lignin dan hemiselulosa, mengurangi kristal selulosa, dan meningkatkan porositas material. Pretreatment harus memenuhi persyaratan sebagai berikut: (1) meningkatkan pembentukan gula atau kemampuan untuk selanjutnya membentuk gula dengan hidrolisa enzimatik; (2) mencegah degradasi atau hilangnya karbohidrat; (3) mencegah pembentukan produk samping yang menghambat proses hidrolisis dan fermentasi; (4) biaya efektif (SunCheng, 2002).

\section{METODOLOGI PENELITIAN}

Peralatan

1. Beaker Gelas $50,100,250,500 \mathrm{~mL}$

2. Erlenmeyer $250 \mathrm{~mL}, 500,1000 \mathrm{~mL}$

3. Gelas ukur $10 \mathrm{~mL}, 50 \mathrm{~mL}$

4. Spatula

5. Autoclave

6. Pipet Tetes

7. Pipet ukur $5 \mathrm{~mL}, 10 \mathrm{~mL}$

8. Neraca Analitik

9. Grinder

10. Oven

11. Batu didih

12. Labu bundar

13. Evaporator

14. Piknometer $5 \mathrm{~mL}$

15. Waterbath

Bahan

1. Ampas Tebu

2. $\mathrm{NaOH} 6 \%$ 


\section{3. $\mathrm{HCl} 0,3 \mathrm{~N}$ \\ 4. Ragi Saccharomyces cerevisiae \\ 5. Aquadest \\ 6. Kertas $\mathrm{pH}$ Universal \\ 7. Kertas Saring}

\section{Rancangan Penelitian}

Penelitian ini bertujuan untuk memanfaatkan limbah ampas tebu menjadi energi alternatif biomassa yaitu bioetanol. Tahapan penelitian terdiri dari dari persiapan bahan baku, alkali pretreatment menggunakan $\mathrm{NaOH}$, Hidrolisa asam encer menggunakan $\mathrm{HCl}$, fermentasi menggunakan ragi Saccharomyces cerevisiae dan kemudian pemurnian bioetanol menggunakan evaporator.

Pada penelitian ini variasi jumlah ragiyang diberikan saat fermentasi, yaitu sebanyak1 gram \% b/v, 3 gram $\%$ b/v, dan 5 gram $\%$ b/v. Selanjutnya variasi waktu fermentasi yang digunakan pada masing-masing jumlah ragi adalah5 hari, 6 hari, 7 hari, 8 hari dan 9 hari.

Ampas tebu diperoleh dari pada pedagang es tebu di pasar indralaya. Ampas tebu berasal dari tebu yang sudah diambil ekstraksi cairan tebu. Ampas tebu dicuci hingga pengotornya hilang kemudian dikeringkan selama $24 \mathrm{jam}$. Ampas tebu yang sudah kering diperkecil ukurannya menjadi $0,5 \mathrm{~mm}$ dengan menggunakan grinder.

\section{Deskripsi Proses}

\section{Alkali Pretreatment}

Ampas tebu seberat 30 gram yang telah berukuran $0,5 \mathrm{~mm}$ dimasukkan ke dalam erlenmeyer $1000 \mathrm{~mL}$ kemudian ditambahkan larutan $\mathrm{NaOH}$ dengan konsentrasi $6 \%$ sebanyak $600 \mathrm{~mL}$. Tutup erlenmeyer dengan gabus kemudian masukkan kedalam plastic steril, selanjutnya panaskan erlenmeyer pada suhu $121^{\circ} \mathrm{C}$ menggunakan autoclave selama 30 menit. Setelah pemanasan dengan autoclave selesai, dinginkan sampel kemudian pisahkan larutan dan padatan. Ampas tebu hasil pretreatment dicuci menggunakan aquadest hingga $\mathrm{pH}$ netral. Keringkan ampas tebu hingga kering pada suhu $80^{\circ} \mathrm{C}$ selama kurang lebih 2 jam.

\section{Hidrolisis Asam}

Ampas tebu seberat 20 gram yang telah kering dimasukkan kedalam erlenmeyer $1000 \mathrm{~mL}$ untuk dihidrolisa. Tambakan $\mathrm{HCl}$ dengan konsentrasi $0,3 \mathrm{~N}$ sebanyak $400 \mathrm{~mL}$. Tutup erlenmeyer dengan menggunakkan gabus kemudian masukkan dalam plastic steril. Perlakuan hidrolisa diberikan dengan memanaskan erlenmeyer yang berisi sampel pada suhu $121^{\circ} \mathrm{C}$ menggunakan autoclave selama 120 menit. Setelah proses selesai, biarkan sampel dingin kemudian pisahkan substrat dan larutan.

\section{Fermentasi dengan Saccharomyces cerevisiae}

Larutan hasil hidrolisa yang mengandung glukosa, selanjutnya difermentasi. Gunakan erlenmeyer $500 \mathrm{~mL}$ yang telah di sterilisasi, kemudian tambahkan ragi Saccharomyces cerevisiae dengan jumlah masing-masing 1 gram $\% \mathrm{~b} / \mathrm{v}, 3$ gram $\% \mathrm{~b} / \mathrm{v}$, dan 5 gram $\% \mathrm{~b} / \mathrm{v}$. Kemudian atur hingga $\mathrm{pH}$ larutan 4.5-5. Sampel yang telah siap, di tutup menggunakan gabus dan hubungkan erlenmeyer dengan botol berisi air menggunakan selang dan biarkan proses fermentasi berlangsung selama 5 hari, 6 hari, 7 hari, 8 hari dan 9 hari. 


\section{Pemurnian Bioetanol dengan Proses Evaporasi}

Siapkan 1 set peralatan evaporasi. Ambil larutan dari hasil fermentasi kemudian masukkan dalam labu, pasang labu pada alat evaporator. Pertahan temperatur pemanas air pada $75^{\circ} \mathrm{C}$ selama 10 menit dan suhu air pendingin pada $15^{\circ} \mathrm{C}$. Simpan bioetanol dalam wadah yang tertutup rapat, simpan dalam lemari pendingin dengan suhu $<5^{\circ} \mathrm{C}$. Analisa kadar bioetanol menggunakan metode densitas.

Pengujian Kadar Bioetanol Metode Densitas

Pengujian kadar bioetanol menggunakan densitas dengan membandingkan hasil perhitungan dengan table densitas bioetanol pada buku Farmakope Indonesia Edisi III. Ukur volume piknometer dengan cara menimbang pikno kosong (a), kemudian catat. Masukkan aquades kedalam piknometer kemudian di timbang (b).Setelah volume piknometer diketahui, hitung densitas sampel dengan memasukkan sampel kedalam piknometer hingga penuh kemudian ditimbang (d). Nilai densitas yang telah diketahui dibandingkan dengan tabel standar analisa densitas bioetanol.
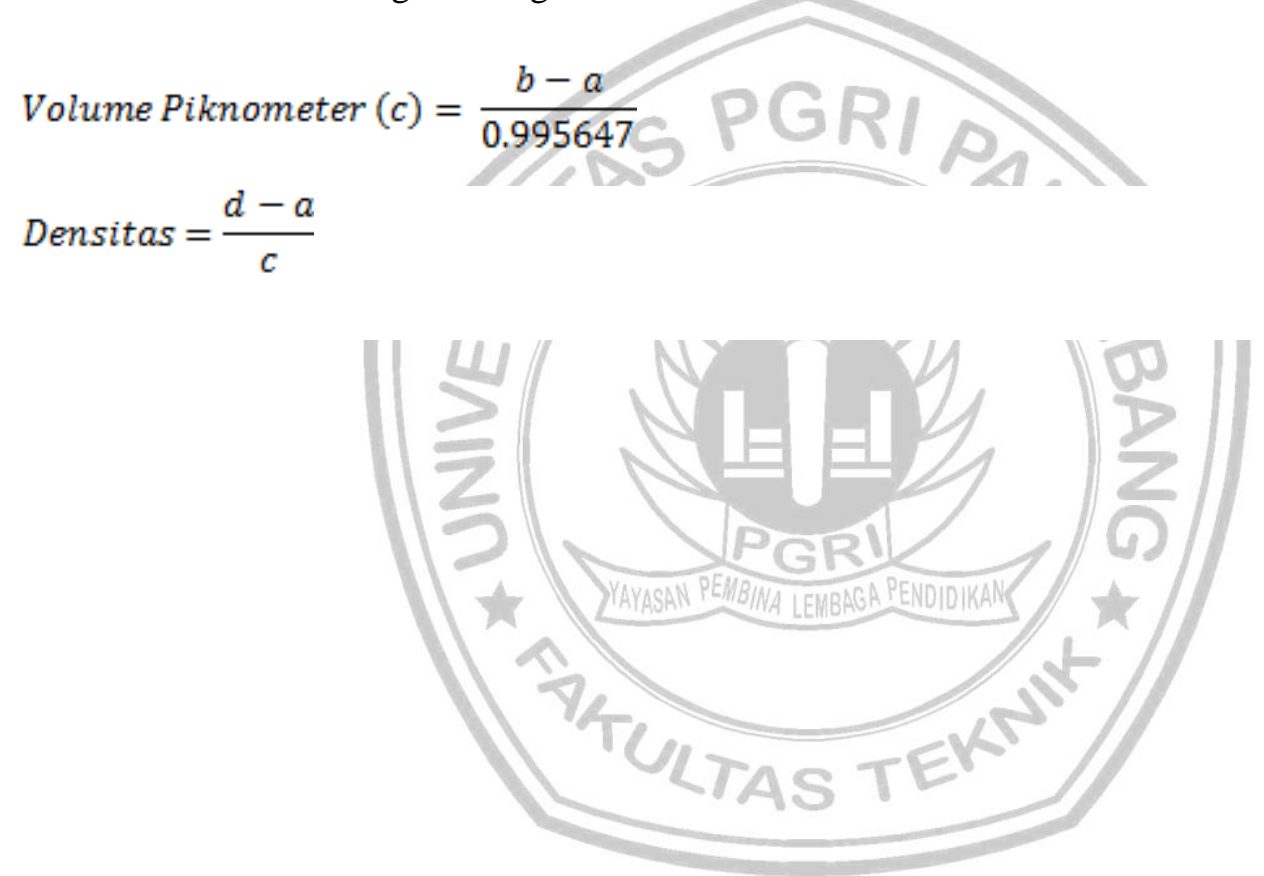


\section{Skema Kerja Proses Penelitian}

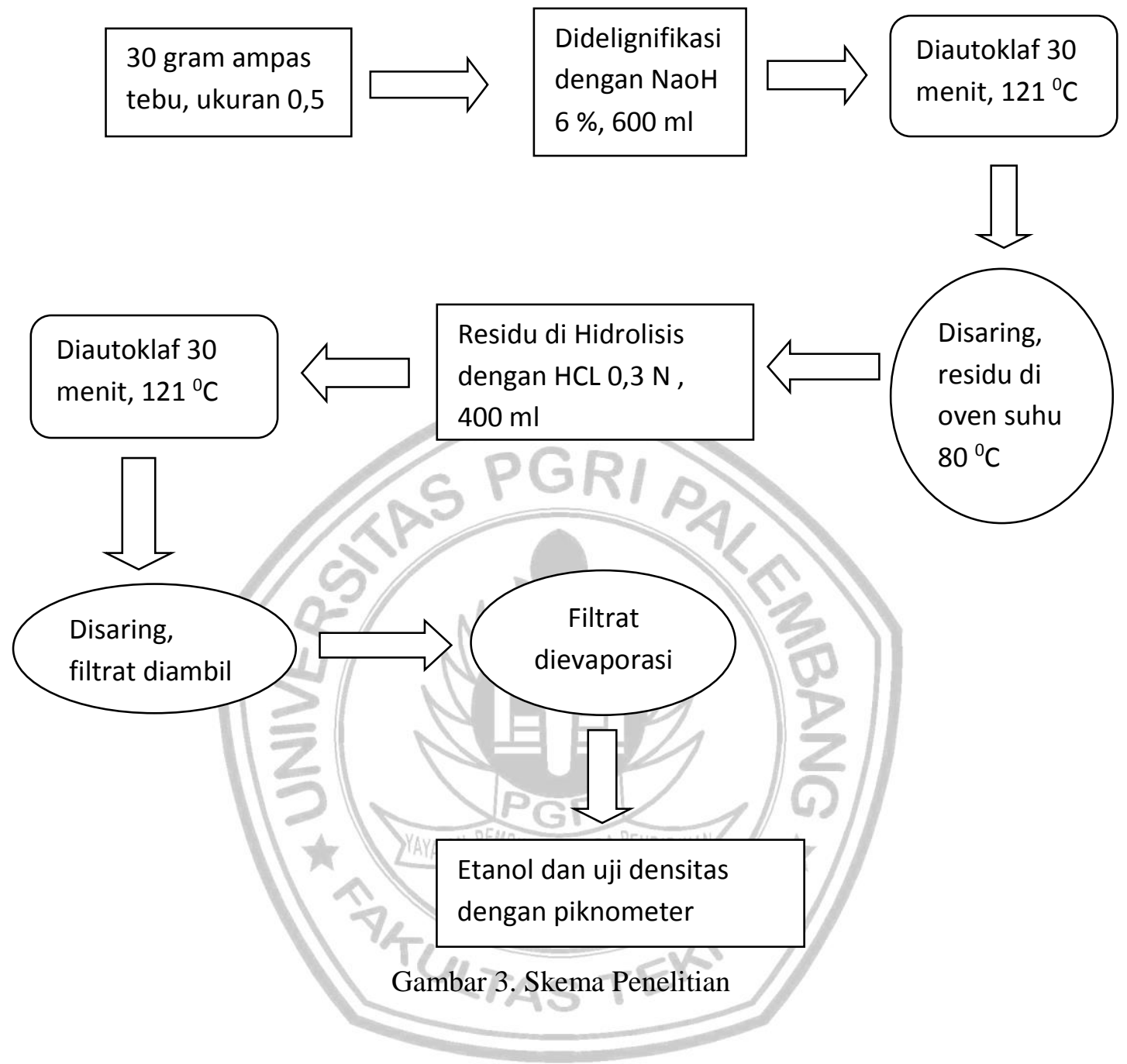

\section{HASIL DAN PEMBAHASAN}

Proses delignifikasi dan hidrolisis ampas tebu

Proses delignifikasi dipengaruhi oleh beberapa faktor, salah satunya adalah ukuran sampel. Menurut Sun \& Cheng (2002) dalam Harry (2014) ukuran partikel akan meningkatkan porositas sampel yang mempengaruhi kontak terhadap senyawa delignifikator dan juga sebagai salah satu cara untuk memutuskan rantai polimer menjadi lebih pendek sehingga lignin lebih mudah untuk terpisah. Semakin kecil ukuran sampel maka akan semakin mudah dalam medagradasi lignin (Harry, 2014).

Setelah menjadi serbuk, sampel di delignifikasi dengan $\mathrm{NaOH} 6 \%$ dipanaskan pada suhu 121 ${ }^{0} \mathrm{C}$ selama 30 menit yang merujuk pada hasil penelitian Ida 2011 dan Harry 2014. Kemudian dinetralkan sampai $\mathrm{pH} 7$ dan dihidrolisis dengan $\mathrm{HCl} 0,3 \mathrm{~N}$ yang merujuk pada hasil penelitian Daniel 2012.

Proses fermentasi ampas tebu pada penelitian ini menggunakan variasi jumlah penambahan ragi, dimana senyawa yang digunakan ialah Saccharomyces Cerevisiae. Jumlah ragi pada larutan hasil hidrolisa untuk fermentasi yaitu 1 gram $\%$ b/v, 3 gram $\%$ b/v, dan 5 gram $\%$ b/v . 
Sistem dalam proses fermentasi harus steril dari udara yang masuk maupun keluar. Sehingga tidak mengganggu sistem kerja dari Saccharomyces Cerevisiae yang bekerja pada sistem anaerob. Kemudian hasil fermentasi dimurnikan dengan menggunakan alat evaporator, dan dianalisa dengan metode densitas. tabel berikut.

Dari hasil penelitian ini didapatkan nilai kadar bioetanol dan waktu lama fermentasi pada

Tabel 3. Hasil analisa kadar bioetanol pada penambahan ragi 1 gram $\% \mathrm{~b} / \mathrm{v}$

\begin{tabular}{|c|c|c|c|c|c|}
\hline \multirow{2}{*}{ NO } & \multirow{2}{*}{ Waktu } & \multicolumn{3}{|c|}{ Kadar Bioetanol (\%) } & $\begin{array}{c}\text { Rata-rata } \\
\text { Kadar } \\
\text { Bioetanol } \\
(\%)\end{array}$ \\
\cline { 3 - 5 } & Fermentasi & Percobaan 1 & Percobaan 2 & Percobaan 3 & 3,1754 \\
\hline 1 & 5 Hari & 3,1578 & 3,1183 & 3,2500 & 3,8382 \\
\hline 2 & 6 Hari & 3,7900 & 3,8426 & 3,8821 & 3,5011 \\
\hline 3 & 7 Hari & 4,4880 & 4,5670 & 4,4484 & 4,50743 \\
\hline 4 & 8 Hari & 3,9348 & 4,0402 & 3,9743 & 3,9831 \\
\hline 5 & 9 Hari & 3,0525 & 3,1183 & 2,9998 & 3,0568 \\
\hline
\end{tabular}

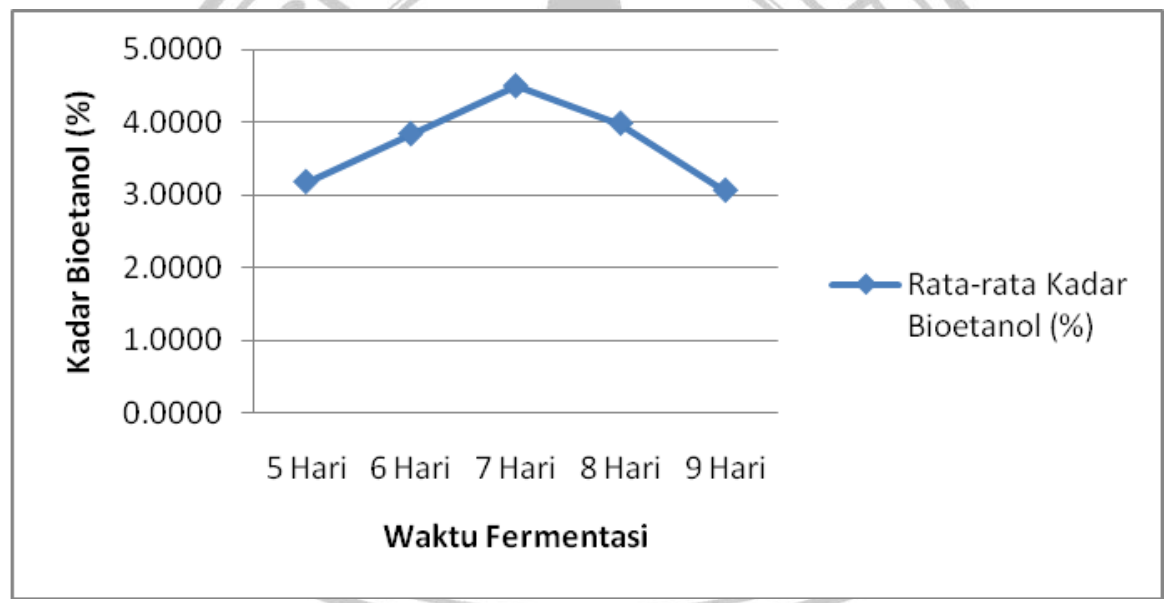

Gambar 4.Pengaruh waktu fermentasi terhadap kadar bioetanol pada penambahan ragi 1 gram $\% \mathrm{~b} / \mathrm{v}$.

Tabel 4. Hasil analisa kadar bioetanol pada penambahan ragi 3 gram $\%$ b/v

\begin{tabular}{|c|c|c|c|c|c|}
\hline \multirow{2}{*}{ NO } & \multirow{2}{*}{ Waktu } & \multicolumn{3}{|c|}{ Kadar Bioetanol (\%) } & $\begin{array}{c}\text { Rata-rata } \\
\text { Kadar } \\
\text { Bioetanol } \\
(\%)\end{array}$ \\
\cline { 3 - 5 } & Fermentasi & Percobaan 1 & Percobaan 2 & Percobaan 3 & \\
\hline 1 & 5 Hari & 4,1587 & 4,1982 & 4,1060 & 4,1543 \\
\hline 2 & 6 Hari & 4,3431 & 4,4089 & 4,3826 & 4,3782 \\
\hline 3 & 7 Hari & 4,4484 & 4,4880 & 4,5933 & 4,5099 \\
\hline 4 & 8 Hari & 4,0534 & 4,0929 & 4,0402 & 4,0621 \\
\hline 5 & 9 Hari & 4,1061 & 4,1324 & 4,1072 & 4,1152 \\
\hline
\end{tabular}




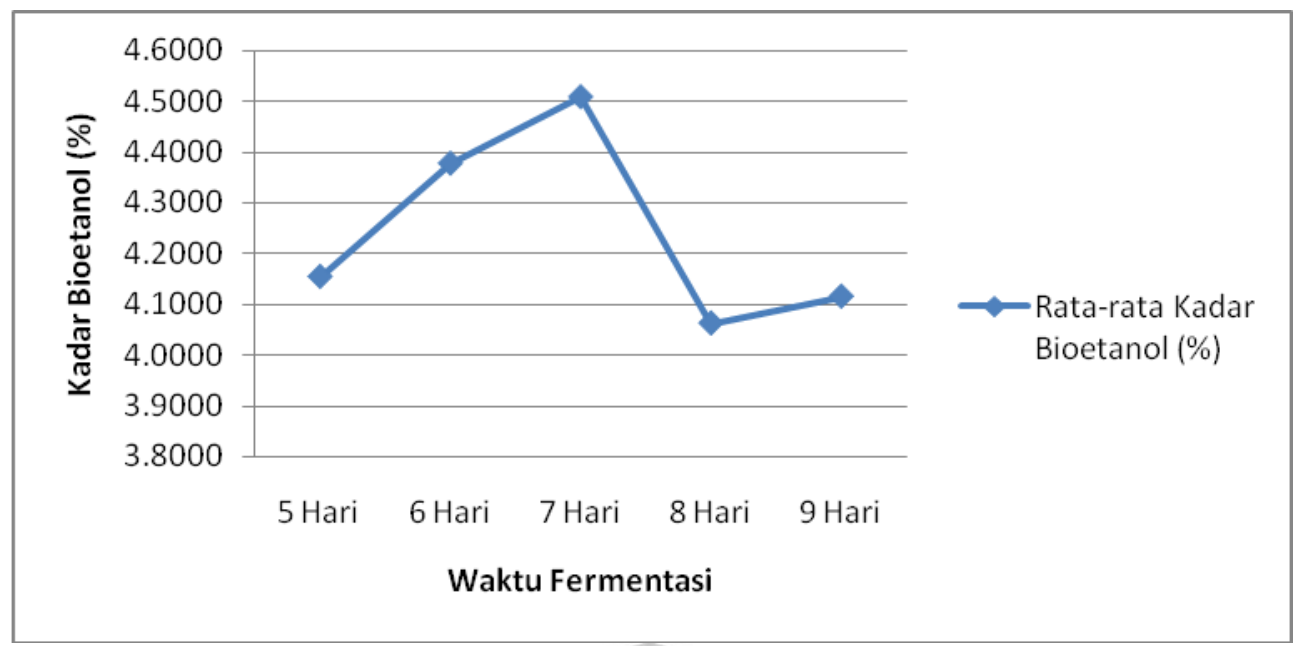

Gambar 5.Pengaruh waktu fermentasi terhadap kadar bioetanol pada penambahan ragi 3 gram $\% \mathrm{~b} / \mathrm{v}$

Tabel 5.Hasil analisa kadar bioetanol pada penambahan ragi 5 gram $\%$ b/v

\begin{tabular}{|c|c|c|c|c|c|}
\hline \multirow{2}{*}{ NO } & \multirow{2}{*}{ Waktu } & \multicolumn{3}{|c|}{ Kadar Bioetanol (\%) } & $\begin{array}{c}\text { Rata-rata } \\
\text { Kadar } \\
\text { Bioetanol } \\
(\%)\end{array}$ \\
\cline { 3 - 5 } & Fermentasi & Percobaan 1 & Percobaan 2 & $\begin{array}{c}\text { Percobaan } \\
3\end{array}$ & 4,2377 \\
\hline 1 & 5 Hari & 4,2246 & 4,3036 & 4,1851 & 4,3606 \\
\hline 2 & 6 Hari & 4,4221 & 4,3563 & 4,3036 & 4,9100 \\
\hline 3 & 7 Hari & 4,8949 & 4,9852 & 4,8498 & 3,9875 \\
\hline 4 & 8 Hari & 3,9480 & 4,0402 & 3,9743 & 3,6790 \\
\hline 5 & 9 Hari & 3,6583 & 3,6679 & 3,7109 & \\
\hline
\end{tabular}

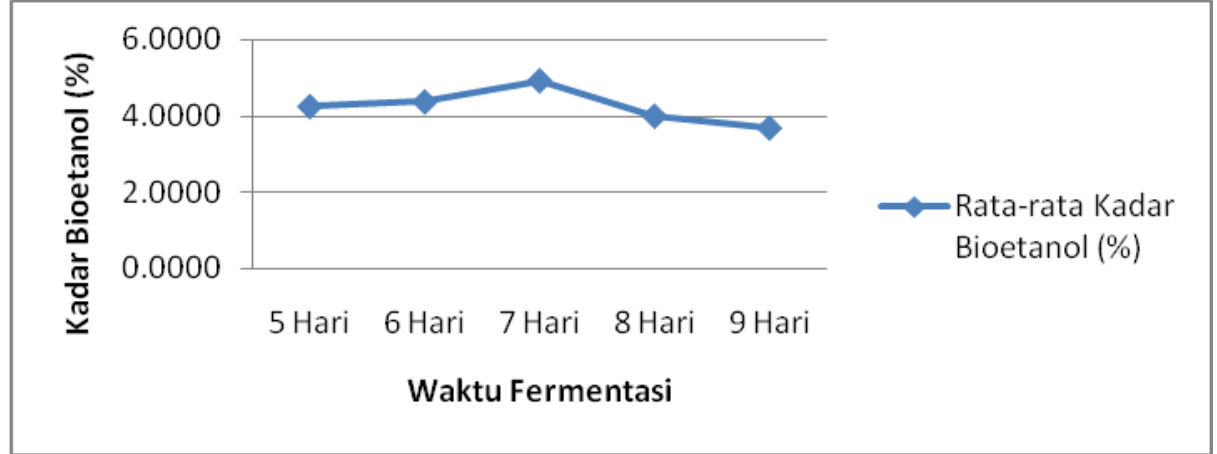

Gambar 6. Pengaruh waktu fermentasi terhadap kadar bioetanol pada penambahan ragi 5 gram $\% \mathrm{~b} / \mathrm{v}$.

Dari tabel 3 sampai dengan 5 dapat dilihat bahwa kadar bioetanol meningkat seiring bertambah banyak jumlah penambahan Saccharomyces Cerevisiae. Kadar bioetanol tertinggi dihasilkan dari penambahan ragi 5 gram \% b/v dengan lama waktu fermentasi 7 hari yaitu 4,9100\% yang ditunjukkan pada tabel 5 dan gambar 6. Sedangkan kadar bioetanol terendah dihasilkan oleh 
sampel pada penambahan ragi 1 gram $\%$ b/v dengan lama waktu fermentasi 9 hari yaitu 3,0568\% yang ditunjukkan pada tabel dan gambar 3.

Tabel 6. Hasil analisa perbandingan kadar bioetanol pada setiap penambahan ragi

\begin{tabular}{|c|c|c|c|c|}
\hline \multirow{2}{*}{ NO } & \multirow{2}{*}{$\begin{array}{c}\text { Waktu } \\
\text { Fermentasi }\end{array}$} & \multicolumn{3}{|c|}{ Rata-rata Kadar Bioetanol (\%) } \\
\cline { 3 - 5 } & perc 1 gram \% b/v & perc 3 gram \% b/v & perc 5 gram \% b/v \\
\hline 1 & 5 Hari & 3,1754 & 4,1543 & 4,2377 \\
\hline 2 & 6 Hari & 3,8382 & 4,3782 & 4,3606 \\
\hline 3 & 7 Hari & 4,5011 & 4,5099 & 4,9100 \\
\hline 4 & 8 Hari & 3,9831 & 4,0621 & 3,9875 \\
\hline 5 & 9 Hari & 3,0568 & 4,1152 & 3,6790 \\
\hline
\end{tabular}

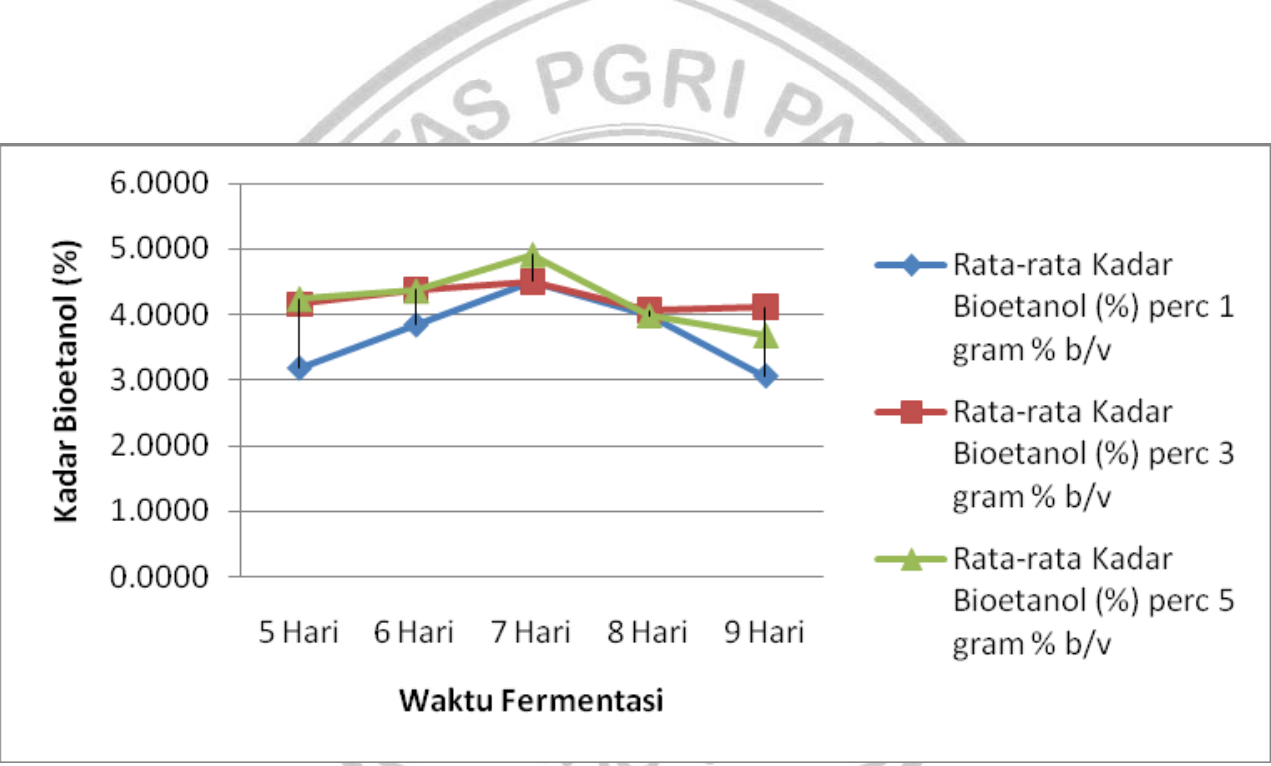

Gambar 7. Pengaruh waktu fermentasi terhadap kadar bioetanol padaSetiap penambahan ragi

Berdasarkan hasil yang ditunjukkan oleh gambar 7 dapat dilihat bahwa kadar bioetanol yang dihasilkan melalui lama waktu fermentasi 7 hari lebih tinggi dibandingkan dengan lama waktu fermentasi 5, 6, 8, dan 9 hari. Hal ini terjadi karena aktivitas Saccharomyces Cerevisiae mengalami fase stationer, dimana terjadi proses pemecahan glukosa secara besar - besaran. Hasil pemecahan glukosa oleh Saccharomyces Cerevisiae menghasilkan etanol.

Menurut (Beni, 2013) Dalam permen ESDM No 32/2008 tentang mandatory Bahan Bakar Nabati, pemerintah telah mengeluarkan esensi peraturan menteri ESDM yang menyebutkan untuk sektor transportasi maka premium harus dicampur dengan $3 \%$ bioetanol. Sesuai dengan esensi peraturan menteri ESDM, bioetanol yang dihasilkan dari proses fermentasi ampas tebu telah memenuhi syarat untuk bisa dijadikan bahan pencampur premium pada sektor transportasi. Selain itu pengujian kadar bioetanol dari proses fermentasi ampas tebu telah memenuhi standar pengujian depertemen kesehatan republik indonesia dengan mengikuti metode pengujian densitas dalam farmakope indonesia edisi III. 


\section{KESIMPULAN}

1. Semakin banyak jumlah ragi yang ditambahkan akan menghasilkan kadar bioetanol yang semakin tinggi.

2. Semakin lama waktu fermentasi akan menghasilkan kadar bioetanol yang yang semakin tinggi pada waktu fermentasi 7 hari.

3. Kadar bioetanol tertinggi terdapat pada jumlah ragi 5 gram $\% \mathrm{~b} / \mathrm{v}$ dan lama waktu fermentasi yang efektif adalah selama 7 hari yaitu $4,9100 \%$.

\section{DAFTAR PUSTAKA}

Agusriyanto, R., dan Fatmawati, A. 2015. Pemodelan Batch Hidrolisa Enzimatis Sabut Kelapa dengan Pengolahan Awal Larutan Basa. Dalam: Prosiding Seminar Nasional TEKNOIN. Surabaya, Universitas Surabaya, pp 24-26, ISBN 978-60214272-1-7

Axelsson, Josefin. 2011. Separate Hydrolysis and Fermentation of Pretreated Spruce. Department of Physics, Chemistry and Biology Linkoping University: Sweden.

Gunam, W. B. I. et. al. 2011. "Delignifikasi Ampas Tebu dengan Larutan Natrium Hidroksida sebelum proses Sakaraifikasi secara Enzimatis menggunakan Enzim Selulase". Jurnal Teknologi Indonesia. vol. 34, agustus, pp 24-32.

Mosier, N., Wyman, C., Dale, B., Elander, R., Lee, Y.Y., Holtzapple, M., Ladisch, M., 2015. Features Of Promising Technologies For Pretreatment Of Lignocellulosic Biomass. Bioresource Technology. 96, 673-686.

Sun, Y., Cheng, J. 2002. Hydrolysis Of Lignocellulosic Materials For Ethanol Production: A Review. Bioresource Technol., 83, 1-11.

Walker, Graeme M. 2010. Bioethanol : Science and Technology of Fuel Alcohol. University of Abertay : Scotland.

Wiratmaja, I. G., Kusuma, I.G. danWinaya, I.N., 2011. "PembuatanEtanol GenerasiKeduaDenganMemanfaatkanLimbahRumputLaut

EucheumaCottoniisebagaiBahan Baku”. Jurnal Ilmiah Teknik Mesin Cakra M. vol. 5, no. 1, april, pp 75-84. 